\title{
Molecular cloning, sequence characterization, and gene expression profile of a novel water buffalo (Bubalus bubalis) gene: $\mathrm{Na}^{+}, \mathrm{K}^{+}$-ATPase $\beta_{2}$-subunit (ATP1B2)
}

\author{
Shen Song ${ }^{1, *}$, Jinlong Huo ${ }^{1, *}$, Feng Yuan', Yina Ou-Yang ${ }^{1}$, DaLin Li ${ }^{2,3}$, YueYun Yuan², Tao \\ Chen $^{4}$, LianJun $\mathrm{Li}^{1}$ and YongWang Miao' \\ ${ }^{1}$ Faculty of Animal Science and Technology, Yunnan Agricultural University, Kunming, China, ${ }^{2}$ Domestic Animal Breeding \\ and Crossbreed-improvement Station of Yunnan Province, Kunming, China, ${ }^{3}$ Yunnan Institute of Bafule Buffalo Science \\ and Technology, Kunming, China, ${ }^{4}$ Animal Husbandry and Veterinary Station of Mangshi city, Mangshi, China
}

\begin{abstract}
The $\mathrm{Na}^{+}, \mathrm{K}^{+}-$ATPase is a transmembrane carrier protein which plays an important role in $\mathrm{Na}-\mathrm{K}$ transport and energy metabolism. The aim of this study was to obtain the full-length coding sequence (CDS) of water buffalo $\mathrm{Na}^{+}, \mathrm{K}^{+}-$ATPase $\beta_{2}$-subunit (ATP1B2) using RT-PCR and to investigate the characterizations of its sequence and tissue expression patterns. Sequence analysis revealed that the CDS of water buffalo ATP1B2 encodes an enzyme of 290 amino acid residues with a deduced molecular weight of $33.39 \mathrm{KDa}$ and a PI of 8.37. Water buffalo ATP1B2 was presumed to have a signal peptide, a strong hydrophobic region and to exert its function in the plasma membrane with high reliability. In addition, water buffalo ATP1B2 has a conserved $\mathrm{Na}^{+}, \mathrm{K}^{+}$-ATPase $\beta$ domain which belongs to $\mathrm{Na}^{+}, \mathrm{K}^{+}$-ATPase superfamily. The sequence of water buffalo ATP1B2 gene shares 97.6, 97.4, 92.2, 93.2, 89.9, 93.2, 89.5 and $62.9 \%$ identify with its homologous sequence of cattle, sheep, dog, human, mouse, baboon, rat and African clawed frog, respectively. Phylogenetic tree analysis based on the CDS of ATP1B2 gene showed that water buffalo has a closer genetic relationship with cattle than with other species. The ATP1B2 gene was widely expressed in the tissues examined, being high in the pituitary gland and brain, moderate in the muscle, spleen, liver, mammary gland, kidney and rumen, weak in the heart, small intestines and skin, and not expressed in the lung and adipose tissue. This study will establish a foundation for further insights into this novel water buffalo gene.
\end{abstract}

*These authors contributed equally to this study.

Archiv Tierzucht 57 (2014) 15, 1-12

doi: $10.7482 / 0003-9438-57-015$

Corresponding author:

Yongwang Miao, email: yongwangmiao999@163.com or miaoyw1@ynau.edu.cn

Faculty of Animal Science and Technology, Yunnan Agricultural University, Kunming, China
Received: 26 July 2013

Accepted: 30 April 2014

Online: 30 June 2014

() 2014 by the authors; licensee Leibniz Institute for Farm Animal Biology (FBN), Dummerstorf, Germany. This is an Open Access article distributed under the terms and conditions of the Creative Commons Attribution 3.0 License (http://creativecommons.org/licenses/by/3.0/). 
Keywords: Water buffalo, $\mathrm{Na}^{+}, \mathrm{K}^{+}$-ATPase $\beta_{2}$-subunit (ATP1B2), bioinformatics analysis, tissue expression analysis

Abbreviations: CDS: coding sequence

\section{Introduction}

Heat stress has huge economic impact on the global dairy industry, and has adverse effects on a variety of productive traits including milk yield, milk composition, growth, carcass and reproduction of dairy cattle, while the heat tolerance can be improved for the high-yielding breeding (Nardone et al. 2000, Wheelock et al. 2010, Baumgard \& Rhoads Jr 2013). That's to say, one possible way to increase milk yield of dairy cattle is to improve heat tolerance and ability of recovery from heat stress of animals. Previous studies showed that animals exposed to heat-stress in environment exhibited a significant change in $\mathrm{Na}^{+}, \mathrm{K}^{+}$-ATPase activity in a variety of tissues (Levy et al. 2005, Pearce et al. 2011). In addition, genetic association study on $\mathrm{Na}^{+}, \mathrm{K}^{+}$-ATPase $\beta_{2}$-subunit gene (ATP1B2) in Chinese Holstein cattle showed that the polymorphisms of ATP1B2 are associated with milk yield, milk composition and heat tolerance (Wang et al. 2011). From the above studies, $\mathrm{Na}^{+}, \mathrm{K}^{+}-$ATPase is especially sensitive to heat stress and its function is to maintain the electrochemical gradient of $\mathrm{Na}^{+}$and $\mathrm{K}^{+}$ions across the cytomembrane, which provides energy for the membrane transport of metabolites, nutrients and ions. Therefore, the cattle $\mathrm{Na}^{+}, \mathrm{K}^{+}$-ATPase gene presents a plausible candidate responsible for heat tolerance traits.

$\mathrm{Na}^{+}, \mathrm{K}^{+}$-ATPase is a transmembrane carrier protein that uses the energy of ATP hydrolysis to transport $\mathrm{Na}^{+}$ions out of and $\mathrm{K}^{+}$ions into the cell (Köksoy 2002). The enzyme has been shown to be composed of three subunits. The a subunit has been implanted in the ion-pumping process (Köksoy 2002, Vague et al. 2004). The $\beta$ subunit is a highly glycosylated protein that interacts with the a subunit and is involved in ion recognition (Köksoy 2002, Vague et al. 2004). The $\gamma$ subunit is a specific, but dispensable component of functional $\mathrm{Na}^{+}, \mathrm{K}^{+}$-ATPase. Each subunit consists of multiple isoforms (Béguin et al. 1997, Barcroft et al. 2002). In the case of a subunit, four isoforms, $a_{1}, a_{2^{\prime}} a_{3^{\prime}}$ and $a_{4}$ are present in mammal cells. The $\beta$ subunit is a type II membrane protein and is necessary for maturation and membrane targeting of the enzyme. There are three isoforms of the $\beta$ subunit, namely $\beta_{1^{\prime}} \beta_{2^{\prime}}$ and $\beta_{3^{\prime}}$ each of them derived from a different gene (Köksoy 2002).

The structure of ATP1B2 gene has been described in the mouse, human, and cattle (Emanuel et al. 1987, Hernando et al. 1994, Avila et al. 1998). The $\beta_{2}$ isoform gene of the mouse is located on chromosome 11, the human ATP1B2 is located on chromosome 17, and the cattle ATP1B2 is located on chromosome 19 (Yang-Feng et al. 1988, Vague et al. 2004). Study in cattle showed that the ATP1B2 gene has six introns, seven exons and its total length is $4310 \mathrm{bp}$, the CDS length of this gene is $873 \mathrm{bp}$, encoding a protein of 290 amino acid residues (Tokhtaeva et al. 2010, Wang et al. 2012). Study in Chinese Holstein cow showed that two novel SNPs, G2258A and C2833T, in the ATP1B2 gene were associated with milk production trait. G2258A significantly affected the milk fat and milk yield, C2833T significantly affected the milk protein and milk yield (Wang et al. 2011).

Water buffalo contributes significantly to the agricultural economy and dairy industry in 
the tropical and subtropical areas (Singh et al. 2000, Khan et al. 2011, Perera 2011). In tropical and subtropical countries, one of the problems to be solved in the dairy industry is the heat stress suffered from dairy cows under hot and humid weather condition. Buffalo is the second largest source of milk supply in the world, and buffalo milk contains less water and more fat, lactose, protein, and minerals than cow milk (Vijh et al. 2008, Mahmood \& Usman 2010, Yindee et al. 2010). The $\mathrm{Na}^{+}, \mathrm{K}^{+}$-ATPase gene maybe represents a candidate gene for heat tolerance traits. Although ATP1B2 gene has been studied in humans, mice and cattle, there is no report on ATP1B2 gene in water buffalo. In this study, we firstly cloned the full-length coding sequence of water buffalo $A T P 1 B 2$ gene, and subsequently did the bioinformatics analysis based on the sequence of ATP1B2 gene obtained, and finally examined its differential expression in tissues by semi-quantitative PCR. These may establish a primary foundation for understanding the mechanisms of heat tolerance in water buffalo.

\section{Material and methods}

\section{Sample collection and CDNA preparation}

All the procedures of sample collection were performed in accordance with the Guide for Animal Care and Use of Experimental animal approved by the Institutional Animal Care and Use Committee of Yunnan Agricultural University. Thirteen fresh tissue samples from the heart, pituitary gland, small intestines, muscle, spleen, liver, mammary gland, skin, lung, brain, kidney, stomach and adipose tissue were collected from three non-lactating water buffaloes (Binglangjiang buffalo) after they had been slaughtered, and another three mammary tissue samples were taken from three lactating water buffaloes (Binglangjiang buffalo). The sampled individuals had no blood relationships at the age of about 54 months. The samples were snap-frozen immediately in liquid nitrogen and then stored at $-80^{\circ} \mathrm{C}$ before processing for RNA isolation.

Total RNA was extracted using RNAiso Plus (TaKaRa, Dalian, China) and treated with RNase-free DNase I (TaKaRa, China) following the manufacturers' instructions. The total RNA $(1 \mu \mathrm{L})$ was checked by $2.0 \%$ agarose gel electrophoresis containing ethidium bromine. The RNA $(3 \mu \mathrm{g})$ was reverse-transcribed with M-MLV reverse transcriptase (Invitrogen, Carlsbad, CA, USA).

\section{Cloning and sequencing of water buffalo ATP1B2 CDS}

The sequence of cattle ATP1B2 gene (acc. no. NM_001035373) and its highly homologous expressed sequence tags, were used to design a set of primers to amplify the complete water buffalo ATP1B2 CDS. The primers were: 5'-AATTGACAGCGGCTGCATATCT-3' (forward) and 5'-GGGTATTCCAGAAGCATCCGTA-3' (reverse). The PCR was performed to isolate the water buffalo ATP1B2 gene using the pooled cDNAs from the mutiple tissue RNAs. The $25 \mu \mathrm{L}$ reaction system contained $2.5 \mu \mathrm{L}$ of $50 \mathrm{ng} / \mu \mathrm{L} \mathrm{cDNA}, 2.0 \mu \mathrm{L}$ of $1.25 \mathrm{mM}$ dNTPs mixed (TaKaRa, China), $12.5 \mu \mathrm{L}$ of 10x Ex-Taq DNA polymerase buffer (Mg2 $2^{+}$Plus), $0.5 \mu \mathrm{L}$ of $10 \mu \mathrm{M}$ forward primer, $0.5 \mu \mathrm{L}$ of $10 \mu \mathrm{M}$ reverse primer, $0.25 \mu \mathrm{L}$ of $5 \mathrm{U} / \mu \mathrm{L}$ Ex Taq DNA polymerase (TaKaRa, China), and $6.25 \mu \mathrm{L}$ of sterile water. The reaction conditions included denaturation for $3 \mathrm{~min}$ at $94^{\circ} \mathrm{C}$, followed by 35 cycles of amplification at $94^{\circ} \mathrm{C}$ for $30 \mathrm{~s}, 55^{\circ} \mathrm{C}$ for $45 \mathrm{~s}$, and $72^{\circ} \mathrm{C}$ for $2 \mathrm{~min}$, and 
then with a final extension at $72^{\circ} \mathrm{C}$ for $5 \mathrm{~min}$. The purified amplified fragment was subcloned into the pMD18-T vector (TaKaRa, China) and then sequenced. At least eight independent positive clones were sequenced. The cDNA segments obtained from sequencing were edited and assembled using DNAstar SeqMan program.

\section{Bioinformatics and sequence analysis}

The software on the ExPASy server (Walker 2005) was used to predict the physical and chemical properties of the putative ATP1B2 protein. Conserved domain prediction was performed using the Conserved Domain Architecture Retrieval Tool of BLAST at the NCBI server. ClustalW software (Thompson et al. 1994) was used for alignment of multiple sequences. Signal peptides were predicted using the SignalP 3.0 server (Dyrløv Bendtsen et al. 2004). ProtComp 9.0 (http://www.softberry.com) was employed to predict protein sorting signals and intracellular localization. Secondary structures of deduced AA sequences were predicted by SOPMA (Geourjon \& Deléage 1995). TMHMM version 2.0 (Krogh et al. 2001) was used to predict transmembrane helices of the protein. Phylogenetic tree (neighbour-joining tree) was constructed based on ATP1B2 gene sequences by applying MEGA v. 4.0 software (Tamura et al. 2007). Statistical significance of groups within phylogenetic trees was evaluated using the bootstrap method with 1000 replications. The three-dimensional structures of the ATP1B2 protein were predicted by the amino acids homology modelling on SWISS-MODEL (Guex \& Peitsch 1997).

\section{Semi-quantification PCR of water buffalo ATP1B2 gene}

To characterize the differential expression, we assayed the mRNA levels of the ATP1B2 gene in 13 tissues of non-lactating water buffalo by semi-quantitative RT-PCR, and to determine its functional role in the mammary gland, we further examined the ATP1B2 gene expression in the mammary tissues of lactating water buffalo. The primers used for semi-quantitative RTPCR were: 5'-CCGTCAAGATGGTCATTC-3' (forward) and 5'-ATCAAGCCTGGTGTAGCC-3' (reverse) (Wang et al. 2012). The RT-PCR were performed using Ex Taq DNA polymerase (TaKaRa, China) according to the manufacturer's protocol. The PCR reaction condition was as follows: predenaturation at $94^{\circ} \mathrm{C}$ for $3 \mathrm{~min}$; then 35 cycles of $94^{\circ} \mathrm{C}$ for $15 \mathrm{~s}, 55^{\circ} \mathrm{C}$ for $45 \mathrm{~s}, 7{ }^{\circ} \mathrm{C}$ for $1 \mathrm{~min}$, followed by a $3 \mathrm{~min}$ extension at $72^{\circ} \mathrm{C}$, and finally to terminate the reaction at $4{ }^{\circ} \mathrm{C}$. To eliminate the effect of cDNAs concentration, we repeated the RT-PCR five times using 1, 2, 3, 4 , and $5 \mu \mathrm{L}$ of the cDNAs as templates, respectively. In this study, water buffalo housekeeping gene $18 \mathrm{~S}$ ribosomal RNA was chosen as the internal reference and was detected with the primers, 5'-GGACATCTAAGGGCATCACAG-3' (forward) and 5'-AATTCCGATAACGAACGAGACT-3' (reverse). Results of semi-quantitative RT-PCR were expressed as the relative quantity of the ATP1B2/18S ribosomal RNA.

\section{Results}

Cloning and identification of water buffalo ATP1B2 complete coding sequence

Being consistent with the expectations, a PCR product of $1167 \mathrm{bp}$ was obtained (Figure 1). The sequencing and open reading frame prediction showed that the full-length coding sequence 


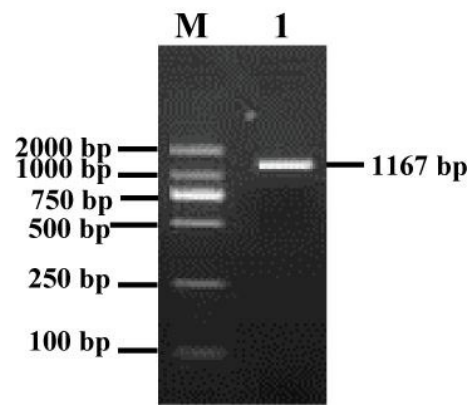

Figure 1

Gel image of RT-PCR product of water buffalo ATP1B2 gene. 1, PCR product for water buffalo ATP1B2 gene. M, DL2000 DNA marker.

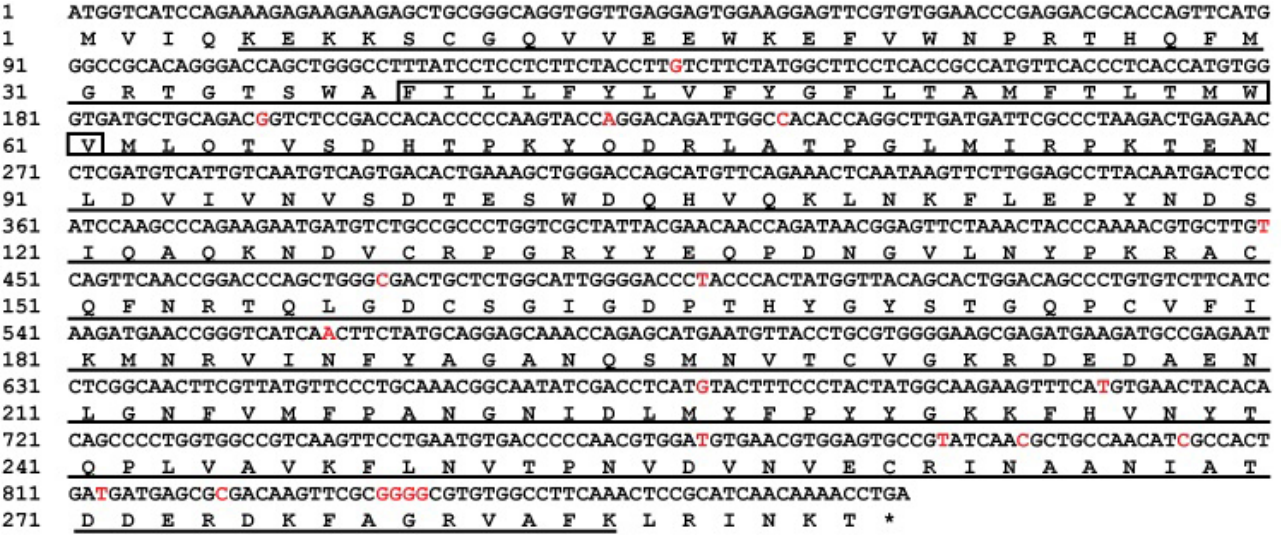

\section{Figure 2}

The complete CDS of water buffalo ATP1B2 gene (acc. no. JX888716) and its encoding amino acid sequences. An asterisk indicates the stop codon; Conserved domain sequences of $\mathrm{Na}^{+} \mathrm{K}^{+}$-ATPase superfamily is underlined. Red characters donate nucleotide different sites of complete ATP1B2 CDS between water buffalo and cattle (NM_174677).

of water buffalo ATP1B2 gene is $873 \mathrm{bp}$ which encoded $290 \mathrm{AA}$. The coding sequence was then submitted to the NCBI database (acc. no. JX888716). The complete CDS of the gene and the deduced $A A$ are presented in figure 2. Comparison of the CDS sequences showed that ATP1B2 gene is conserved throughout the mammals. BLAST analysis revealed that water buffalo ATP1B2 gene shares high homology with Bos taurus (97.6\%), Ovis aries (97.4\%), Canis lupus familiaris (92.2\%), Homo sapiens (93.2\%), Mus musculus (89.9\%), Papio anubis (93.2\%), Rattus norvegicus (89.5\%), and has a lower homology with Xenopus laevis (62.9\%) at the nucleotide level. The coding region sequence of ATP1B2 gene has an overall base composition of $25.43 \%$ A, $27.72 \%$ C, $25.09 \%$ G, and $21.76 \%$ T. There are 4 non-synonymous substitutions for the coding region sequences of the ATP1B2 gene between water buffalo and cattle. They are c.560 A>G, c.678 G>A, c.684 T>C, c.835 G>C, and c.836 G>C, which lead to the corresponding deduced amino acid changes at p.187 (N>S), p.226 (M>I), p.256 (D>E) and p.279 (G>P), respectively. 


\section{Phylogenetic tree construction of ATP1B2}

Phylogenetic tree was constructed based on the nucleotide sequences of the ATP1B2 gene. The sequences from mammals form four subgroups: Bovidae family, primate, Canine family and rodent. Water buffalo has a closer genetic relationship with the species of Bovidae family (cattle and sheep).

\section{Amino acid sequence analysis and protein characteristics}

The molecular weight and theoretical pl for the deduced amino acid sequence of water buffalo ATP1B2 are $33.39 \mathrm{kD}$ and 8.37, respectively. Bioinformatic analysis showed that Water buffalo ATP1B2 has a $53 \mathrm{AA} \mathrm{N}$-terminal signal peptide (Figure $4 \mathrm{~A}$ ) and it functions in the plasma membrane with high reliability (score: 9.93). Conserved domains of $\mathrm{Na}^{+}, \mathrm{K}^{+}$ATPase superfamily in water buffalo was displayed as figure 2 (AA 5-284). Hydrophobicity structure prediction showed that water buffalo ATP1B2 contains a strong hydrophobicity domain (Figure 4B). Conserved domain prediction indicated that the ATP1B2 has a $\mathrm{Na}^{+}, \mathrm{K}^{+}$-ATPase $\beta$ domain which belongs to $\mathrm{Na}^{+}, \mathrm{K}^{+}$-ATPase superfamily (AA 5-284) (Figure 5). Two $\mathrm{Na}^{+}, \mathrm{K}^{+}$-ATPase $\beta$ subunit signatures were found in the ATP1B2, which are 17-WkeFvWNprthqfMGRTgtsW-37 and 147-KraCQfnrtqLgdCSG-163, respectively. The putative amino acid sequence of the ATP1B2 contains 5 potential N-Glycosylation sites. They are at p.96, p.118, p.197, p.238 and p.288 of the protein. The prediction of secondary structure by SOPMA indicated that the deduced ATP1B2 of water buffalo contains 79 AA alpha helices, 53 AA extended strands, 6 AA beta turns and $152 \mathrm{AA}$ random coils (Figure 6), which suggested that a significant portion of the amino acids of the ATP1B2 are most likely to form random coils. The three-dimensional structure of the ATP1B2 (AA 23-289) (Figure 7A) predicted by homology modeling is similar to that of pig ATP1A1 (Figure 7B).

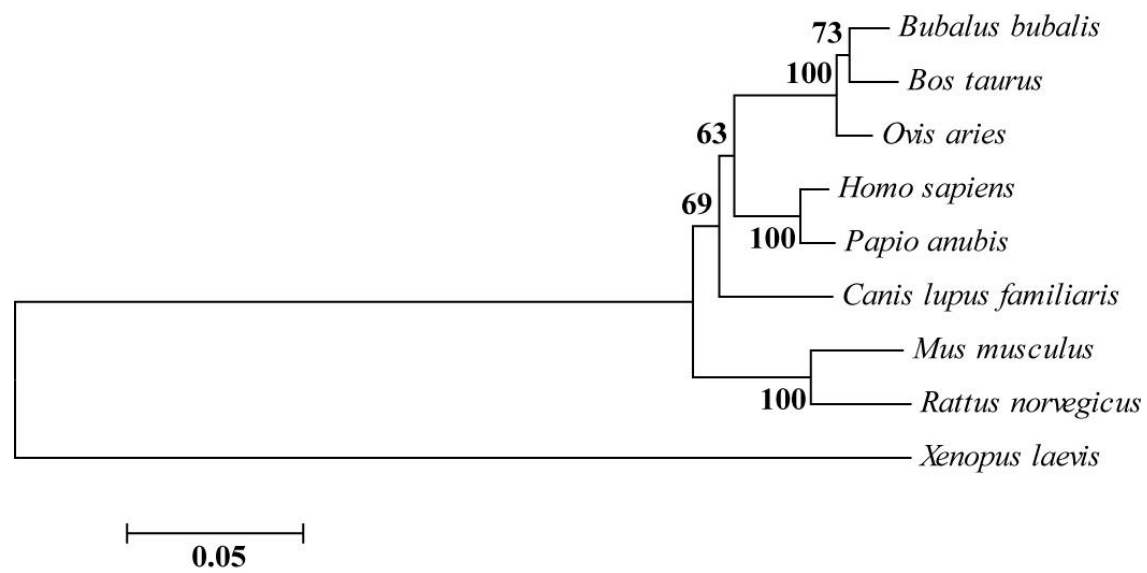

Figure 3

Phylogram based on ATP1B2 gene sequences using the neighbor-joining method. The nucleotide sequence of water buffalo ATP1B2 and the ATP1B2 of other species were used in this analysis. Bos taurus (cow) NM_174677, Ovis aries (sheep) XM_004012670, Homo sapiens (human) NM_001678, Papio anubis (baboon) XM_003912271, Mus musculus (mouse) NM_013415, Rattus norvegicus (rat) NM_012507 and Xenopus laevis (African clawed frog) NM_001086893. 

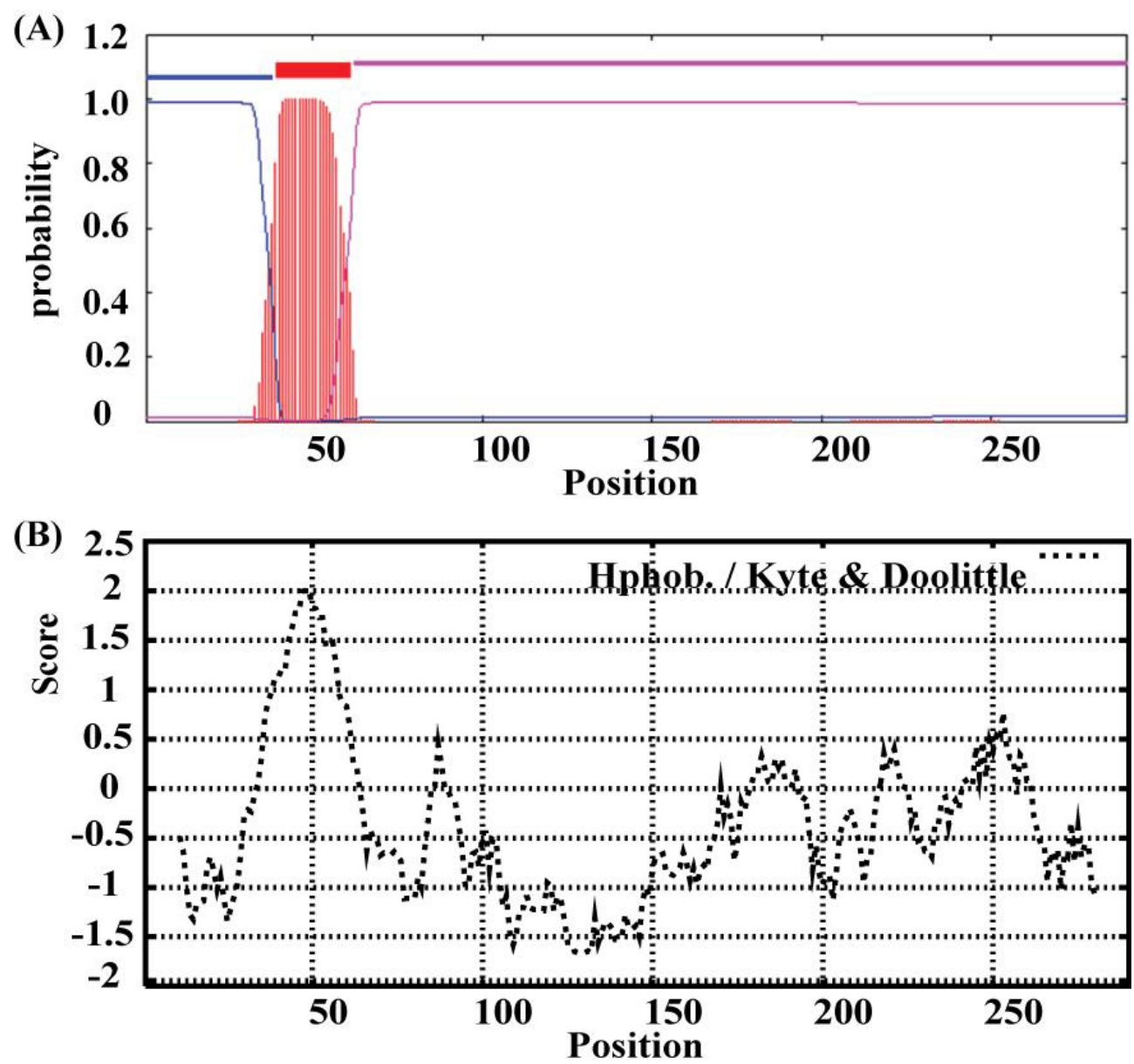

Figure 4

Transmembrane regions (A) and hydrophobicity profile (B) of water buffalo ATP1B2 generated with the ProtScale. Score $>0$ means hydrophobic; score $<0$ means hydrophilic.

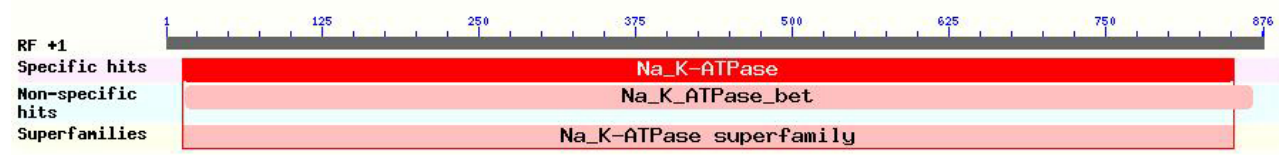

Figure 5

The putative conserved domain of the protein encoded by water buffalo ATP1B2 gene.

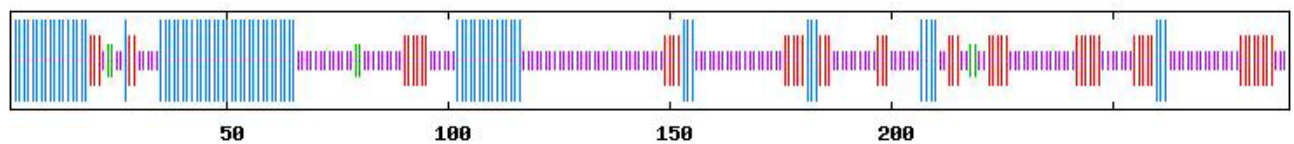

Figure 6

Predicted secondary structure of the water buffalo ATP1B2 protein by SOPMA. Alpha helices, extended strands, beta turn, random coils are indicated with the longest, second longest, third longest and shortest vertical lines, respectively. 


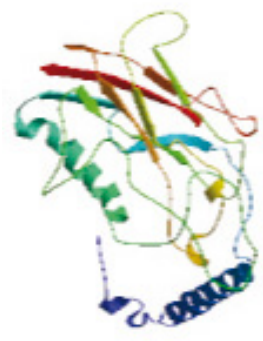

(A)

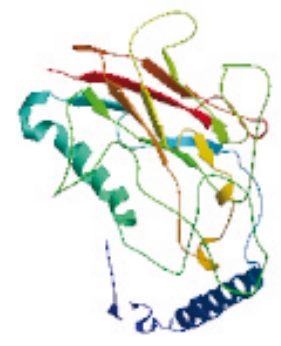

(B)

\section{Figure 7}

The tertiary structure of buffalo ATP1B2 predicted by SWISS-MODEL. (A) Putative tertiary structure of buffalo ATP1B2. (B) Tertiary structure of pig ATP1A1

\section{Tissue expression profile analysis of water buffalo ATP1B2 gene}

The differential expression analysis showed the ATP1B2 gene was widely expressed in the examined tissues of non-lactating water buffalo (Figure $8 \mathrm{~A}$ ), being high in the pituitary gland and brain, moderate in the muscle, spleen, liver, mammary gland, kidney and rumen, weak in the heart, small intestines and skin, and not expressed in the lung and adipose tissue. As can be seen in figure $8 \mathrm{~B}$, the ATP1B2 gene displayed differential expression in the mammary tissues of non-lactating and lactating stages. The expression level of water buffalo ATP1B2 gene in the mammary glands at lactating stage is higher than at non-lactating stage.

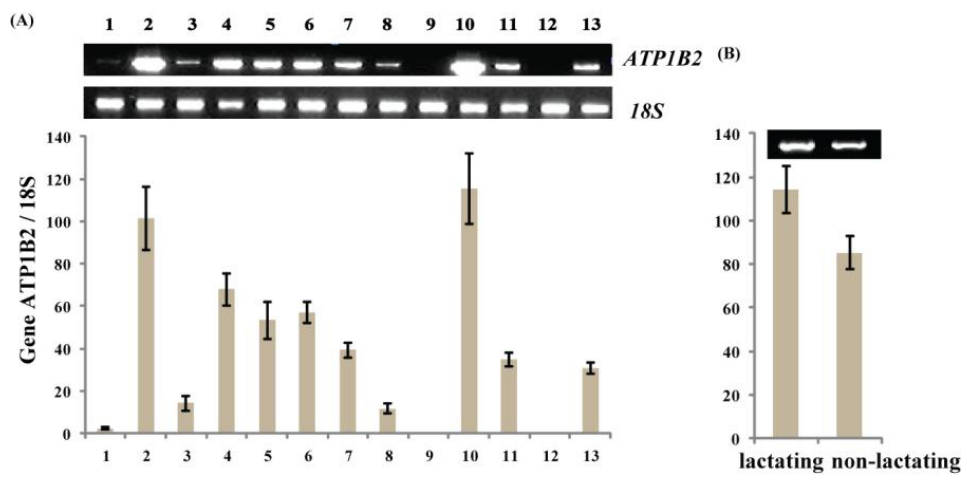

Figure 8

(A) The expression levels of ATP1B2 gene in 13 water buffalo tissues. (B) The differential expressions of water buffalo ATP1B2 gene in the mammary gland between lactating and non-lactating stage.

Note: (A) 1-heart, 2-pituitary gland, 3-small intestine, 4-muscle, 5-spleen, 6-liver, 7-mammary gland, 8-skin, 9-lung, 10-brain, 11-kidney, 12-adipose tissue, 13-rumen, M, DNA marker (DL2000).

\section{Discussion}

The $\mathrm{Na}^{+}, \mathrm{K}^{+}$-ATPase is an ubiquitous membrane enzyme which plays important roles in preserving the ionic gradients across the cell membrane and thus the membrane potential and osmotic equilibrium of the cell (Köksoy 2002, Vague et al. 2004). In the present study, the complete coding sequence of water buffalo $\mathrm{Na}^{+}, \mathrm{K}^{+}$-ATPase $\beta_{2}$-subunit (ATP1B2) was amplified and identified using the RT-PCR based on in silico cloning. The data confirmed that 
the cloned sequence in this study encoded a new water buffalo gene. The full-length coding sequence of the ATP1B2 gene contains 873 nucleotides encoding a putative protein of 290 $\mathrm{AA}, 33.4 \mathrm{kDa}$ in size, with a $\mathrm{pl}$ of 8.37 . The results of protein analysis indicated that water buffalo ATP1B2 contains a $\mathrm{N}$-terminal signal-anchor sequence, a transmembrane domain and a $\mathrm{Na}^{+}, \mathrm{K}^{+}-$ATPase $\beta$ domain, and it functions in the plasma membrane with high reliability. In addition, hydrophobicity structure prediction showed that there is a strong hydrophobicity structure in water buffalo ATP1B2, which was consistent with the result of transmembrane structure prediction. The above results suggest that the water buffalo ATP1B2 is a membrane protein, and it possesses the characteristics shared by all the $\mathrm{Na}^{+}, \mathrm{K}^{+}-$ATPase superfamily members, which supports that it involves in transporting $\mathrm{Na}^{+}$ions out of and $\mathrm{K}^{+}$ions into the cell as a transmembrane carrier protein (Köksoy 2002).

$\mathrm{N}$-glyscans can stabilize the tertiary structure of glycoproyeins and comprised the binding sites for the endoplasmic reticulum-resident lectins. Also, they assist a correct folding of newly synthesized glycoproteins and they are crucial for maturation of the $\mathrm{Na}^{+}, \mathrm{K}^{+}-A T P a s e \beta_{2}$ subunit (Tokhtaeva et al. 2010). Previous study in human showed that there are $8 \mathrm{~N}$-Glycosylation sites in the ATP1B2, and two N-Glycosylation sites (Asn118 and Asn238) are essential for calnexinmediated folding and quality control of the former $\mathrm{Na}^{+}, \mathrm{K}^{+}-\mathrm{ATPase} \beta_{2}$ subunit (Tokhtaeva et al. 2010). But in the present study, only five N-Glycosylation sites (Asn 96, Asn 118, Asn 197, Asn 238 and Asn 288) were predicted in water buffalo ATP1B2. All of these five N-Glycosylation sites were located in the $\mathrm{Na}^{+}, \mathrm{K}^{+}$ATPase $\beta$ chain domain. Alignment analysis showed that two $\mathrm{N}$-Glycosylation sites of ATP1B2 are quite conserved in the species of cattle, sheep, human, baboon, mouse, rat and African clawed frog. This implies water buffalo ATP1B2 probably have similar functions as the ATP1B2 of human or other species. However, the differences in $\mathrm{N}$-Glycosylation site number between humans and water buffalo may be implied they have some functional differences.

Homology analysis showed that water buffalo ATP1B2 has high identity with other mammal species at the nucleotide level, indicating that the ATP1B2 is functionally conserved among different mammal species. Compared to other species, water buffalo ATP1B2 has higher identity with cattle and sheep. This implies that the ATP1B2 gene in water buffalo is more similar functionally to cattle and sheep.

The subunit composition of the $\mathrm{Na}^{+}, \mathrm{K}^{+}$-ATPase is tissue-specific. In order to investigate the distribution of $A T P 1 B 2$ in water buffalo tissues, we have examined the expression profile of the water buffalo ATP1B2 gene by employing semi-quantitative RT-PCR. The ATP1B2 gene is widely expressed in the diverse tissues of adult buffalo at different levels within an individual organism. The results in this study showed that water buffalo ATP1B2 gene was expressed in all tested tissues except the lung and adipose tissue. Gene expression in which parts of animals was related to its corresponding gene functions. So, we speculate that water buffalo ATP1B2 gene may play roles in the diverse tissues, especially in the pituitary gland, brain, muscle, spleen, liver, mammary gland, kidney and rumen. The ATP1B2 was extremely abundant in the brain, which was consistent with the result from adult rat (Martin-Vasallo et al. 1989). The tissue expression profiles from six cattle cDNA libraries in NCBI database (http://www.ncbi.nlm.nih.gov/UniGene/ESTProfileViewer.cgi?uglist=Bt.91787) show that the cattle ATP1B2 gene is only expressed in the brain, adrenal gland, kidney, intestine and muscle. Compared with the tissue distribution in cattle, water buffalo ATP1B2 gene showed obviously 
different expression patterns. The reason for expression differences between cattle and water buffalo needs further investigation.

In the present study, gene expression analysis showed that water buffalo ATP1B2 gene was moderately expressed in the mammary gland, and the expression level of the ATP1B2 gene was found to be higher in lactating than in non-lactating stage. This phenomenon may be interpreted as that $\mathrm{Na}^{+}, \mathrm{K}^{+}$-ATPase has a rapid turnover and resynthesis in lactating mammary gland as mentioned in a previous study (Martin-Vasallo et al. 1989).

Genetic association studies have revealed that the ATP1B2 gene has an important influence on milking performance in cattle. A prior study on Chinese-Holstein cattle showed that two novel single polymorphisms, G2258A and C2833T, in the second and fourth introns of ATP1B2 gene have a significant impact on the milk traits (Wang et al. 2011). G2258A significantly affected milk fat content and 305-day milk yield, and C2833T significantly affected milk protein content and 305-day milk yield. Also, the single nucleotide polymorphism of C2833T of ATP1B2 gene is a genetic marker of heat-tolerance traits (Wang et al. 2011). However, there have been no genetic association studies of polymorphisms in the ATP1B2 gene with milk traits in water buffalo. This study provides a molecular basis for detecting the polymorphisms of water buffalo ATP1B2 gene in population samples, and further unfolding the genetic association between the polymorphisms and the physiological process controlled by this protein.

In conclusion, we firstly identified water buffalo ATP1B2 gene in this study. By conducting necessary bioinformatics analysis and tissue expression profile analysis, we clarified some characteristics and potential functions of water buffalo ATP1B2. These informations will provide the primary foundation for further insights into the role and functional mechanism of water buffalo ATP1B2 gene.

\section{Acknowledgements}

This study was financially supported by the Natural Science Foundation Key Project of Yunnan Province, China (No. 2007C0003Z), the National Natural Science Foundation of China (No. 30660024), the Applied and Basic Research Foundation of Yunnan Province, China (No. 2006C0034M) and the Foundation of Yunnan Department of Finance, China (Study on the germplasm characteristics of Binglangjiang buffalo).

\section{References}

Amaral MEJ, Grant JR, Riggs PK, Stafuzza NB, Filho EAR, Goldammer T, Weikard R, Brunner RM, Kochan KJ, Greco AJ, Jeong J, Cai Z, Lin G, Prasad A, Kumar S, Saradhi GP, Mathew B, Kumar MA, Miziara MN, Mariani P, Caetano AR, Galvão SR, Tantia MS, Vijh RK, Mishra B, Kumar STB, Pelai VA, Santana AM, Fornitano LC, Jones BC, Tonhati H, Moore S, Stothard P, Womack JE (2008) A first generation whole genome RH map of the river buffalo with comparison to domestic cattle. BMC Genomics 9, 631

Avila J, Alvarez de la Rosa D, González-Martínez LM, Lecuona E, Martín-Vasallo P (1998) Structure and expression of the human $\mathrm{Na}$, K-ATPase $\beta_{2}$-subunit gene. Gene 208, 221-227

Barcroft LC, Gill SE, Watson AJ (2002) The gamma-subunit of the Na-K-ATPase as a potential regulator of apical and basolateral $\mathrm{Na}^{+}$-pump isozymes during development of bovine pre-attachment embryos. Reproduction 124, 387-397 
Baumgard LH, Rhoads Jr RP (2013) Effects of Heat Stress on Postabsorptive Metabolism and Energetics. Annu Rev Anim Biosci 1, 311-337

Béguin P, Wang X, Firsov D, Puoti A, Claeys D, Horisberger JD, Geering K (1997) The $\gamma$ subunit is a specific component of the Na, K-ATPase and modulates its transport function. EMBO J 16, 4250-4260

Dyrløv Bendtsen J, Nielsen H, von Heijne G, Brunak S (2004) Improved Prediction of Signal Peptides: SignalP 3.0. J Mol Biol 340, 783-795

Emanuel JR, Garetz S, Stone L, Levenson R (1987) Differential expression of $\mathrm{Na}^{+}, \mathrm{K}^{+}$-ATPase alpha- and betasubunit mRNAs in rat tissues and cell lines. Proc Natl Acad Sci U S A 84, 9030-9034

Geourjon C, Deléage G (1995) SOPMA: significant improvements in protein secondary structure prediction by consensus prediction from multiple alignments. Comput Appl Biosci 11, 681-684

Guex N, Peitsch MC (1997) SWISS-MODEL and the Swiss-Pdb Viewer: An environment for comparative protein modeling. Electrophoresis 18, 2714-2723

Hernando N, Martin-Vasallo P, Ghosh S, Ghosh PK, Swaroop A, Coca-Prados M (1994) Nucleotide sequence of a CDNA for the $\beta_{2}$ subunit isoform of $\mathrm{Na}^{+}, \mathrm{K}^{+}$-ATPase from human retina. Biochim Biophys Acta Biomembranes $1189,109-111$

Köksoy AA (2002) Na+, $\mathrm{K}^{+}$-ATPase: A review. J Ankara Med Sch 24, 73-82

Khan FA, Nabi SU, Pande M, Das GK, Sarkar M (2011) Bilateral follicular cysts in a water buffalo. Trop Anim Health Prod 43, 539-541

Krogh A, Larsson B, von Heijne G, Sonnhammer ELL (2001) Predicting transmembrane protein topology with a hidden markov model: application to complete genomes. J Mol Biol 305, 567-580

Levy B, Gibot S, Franck P, Cravoisy A, Bollaert PE (2005) Relation between muscle $\mathrm{Na}^{+} \mathrm{K}^{+}$ATPase activity and raised lactate concentrations in septic shock: a prospective study. Lancet 365, 871-875

Mahmood A, Usman S (2010) A Comparative Study on the Physicochemical Parameters of Milk Samples Collected from Buffalo, Cow, Goat and Sheep of Gujrat, Pakistan. Pak J Nutri 9, 1192-1197

Martin-Vasallo P, Dackowski W, Emanuel JR, Levenson R (1989) Identification of a putative isoform of the $\mathrm{Na}$, K-ATPase beta subunit. Primary structure and tissue-specific expression. J Biol Chem 264, 4613-4618

Michelizzi VN, Dodson MV, Pan Z, Amaral MEJ, Michal JJ, McLean DJ, Womack JE, Jiang Z (2010) Water Buffalo Genome Science Comes of Age. Int J Biol Sci 6, 333-349

Nardone A, Valentini A (2000) The genetic improvement of dairy cows in warm climates. In: Guessous F, Rihani $\mathrm{N}$, llham $\mathrm{A}$ (eds.) Livestock production and climatic uncertainty in the Mediterranean. Proceedings of the joint ANPA-EAAP-CIHEAM-FAO symposium, Agadir, Morocco, 22-24 October 1998, Wageningen Pers, EAAP Pub. No. 94, 185-191

Pearce SC HAJ, Gabler NK, Baumgard LH (2011) Effects of heat stress on $\mathrm{Na}^{+} / \mathrm{K}^{+} A T P a s e$ activity in growing pigs. J Anim Sci 89 (E-Suppl. 1), 596

Perera BMAO (2011) Reproductive cycles of buffalo. Anim Reprod Sci 124, 194-199

Singh J, Nanda AS, Adams GP (2000) The reproductive pattern and efficiency of female buffaloes. Anim Reprod Sci 60-61, 593-604

Tamura K, Dudley J, Nei M, Kumar S (2007) MEGA4: Molecular Evolutionary Genetics Analysis (MEGA) Software Version 4.0. Mol Biol Evol 24, 1596-1599

Thompson JD, Higgins DG, Gibson TJ (1994) CLUSTAL W: improving the sensitivity of progressive multiple sequence alignment through sequence weighting, position-specific gap penalties and weight matrix choice. Nucl Acids Res 22, 4673-4680

Tokhtaeva E, Munson K, Sachs G, Vagin O (2010) N-glycan-dependent quality control of the Na, K-ATPase $\beta_{2}$ subunit. Biochemistry 49, 3116-3128

Vague P, Coste TC, Jannot MF, Raccah D, Tsimaratos M (2004) C-peptide, $\mathrm{Na}^{+}, \mathrm{K}^{+}-A T P a s e$, and Diabetes. Exp Diabesity Res 5, 37-50

Vijh RK, Tantia MS, Mishra B, Bharani Kumar ST (2008) Genetic relationship and diversity analysis of Indian water buffalo (Bubalus bubalis). J Anim Sci 86, 1495-1502 
Walker JM (2005) The Proteomics Protocols Handbook. Totowa, NJ, USA

Wang Z, Huang J, Zhong J, Wang G (2012) Tissue-specific alternative splicing and expression of ATP1B2 gene. Afr J Biotechnol 11, 9485-9495

Wang Z, Wang G, Huang J, Li Q, Wang C, Zhong J (2011) Novel SNPs in the ATP1B2 gene and their associations with milk yield, milk composition and heat-resistance traits in Chinese Holstein cows. Mol Biol Rep 38, 1749-1755

Wheelock JB, Rhoads RP, VanBaale MJ, Sanders SR, Baumgard LH (2010) Effects of heat stress on energetic metabolism in lactating Holstein cows. J Dairy Sci 93, 644-655

Yang-Feng TL, Schneider JW, Lindgren V, Shull MM, Benz Jr EJ, Lingrel JB, Francke U (1988) Chromosomal localization of human $\mathrm{Na}^{+}, \mathrm{K}^{+}$-ATPase $\alpha$-and $\beta$-subunit genes. Genomics 2, 128-138

Yindee M, Vlamings BH, Wajjwalku W, Techakumphu M, Lohachit C, Sirivaidyapong S, Thitaram C, Amarasinghe AAAWK, Alexander PABDA, Colenbrander B, Lenstra JA (2010) Y-chromosomal variation confirms independent domestications of swamp and river buffalo. Anim Genet 41, 433-435 